\title{
Pengaruh Penerapan Metode Bermain Peran Terhadap Aspek Perkembangan Sosial Emosional Anak
}

\author{
Laila Nurjannah \\ Email: Nurjannah.laila@rocketmail.com
}

Zalyana

Email:zalyanaan@ymail.com

Program Studi Pendidikan Islam Anak Usia Dini Fakultas Tarbiyah dan Keguruan Universitas Islam Negeri Sultan Syarif Kasim Riau, Indonesia

\begin{abstract}
This study aims to determine the effect of role playing methods on aspects of emotional social development of group B children in Kindergarten (TK) Pondok Pesantren Babussalam Pekanbaru. This research is an experimental research using one-group pretest-posttest design to know comparison before and after treatment. The subjects of this study were 5-6 year old students group B, and the object of research is the influence of role playing methods on aspects of emotional social development. The population of this research is students in kindergarten Pondok Pesantren Babussalam Pekanbaru amounting to 60 children, with a sample of 20 children consisting of class B1 control class as much as 10 children, and B2 that is experimental class as many as 10 children. The sample is done by purposive sampling technique, that is by determining the sample through certain consideration. Data collection techniques used are observation and documentation. While the technique of data analysis using t-test test using SPSS Windows ver. 15. The results showed that thitung $=56.236$ with Sig $=0,000$. Because the sig $<0,05$ it can be concluded that there is significant influence after the treatment in role play method. So Ho rejected Ha accepted which means there is influence before and after being given treatment to emotional social development of children. Influence of role playing method toward emotional social development aspect of group $B$ children in kindergarten (TK) Pondok Pesantren Babussalam Pekanbaru is 92,17\%.
\end{abstract}

Keywords : Emotional Social Development; Methods Role Playing

\begin{abstract}
Abstrak
Penelitian ini bertujuan untuk mengetabui pengarub metode bermain peran terhadap aspek perkembangan sosial emosional anake kelompok B di Taman Kanak-Kanak (TK) Pondok Pesantren Babussalam Pekanbaru. Penelitian ini adalab penelitian eksperimen yang menggunakan one-group pretest-posttest design untuk. mengetabui perbandingan sebelum dan sesudah diberi perlakuan. Subjek penelitian ini adalah peserta didik usia 5-6 tabun kelompok B, dan objek penelitian adalah pengaruh metode bermain peran terhadap aspek perkembangan sosial emosional. Populasi penelitian ini adalab anak didik di TK Pondok Pesantren Babussalam Pekanbaru berjumlah 60 anak, dengan sampel berjumlah 20 anake yang terdiri dari kelas B1 yaitu kelas kontrol sebanyak 10 anak, dan B2 yaitu kelas
\end{abstract}


eksperimen sebanyak 10 anak. Sampel dilakukan dengan teknik purposive sampling, yaitu dengan penentuan sampel melalui pertimbangan tertentu. Teknik, pengumpulan data yang digunakan adalah observasi dan dokumentasi.Sedangkan teknik analisis data menggunakan uji t-test dengan menggunakan program SPSS Windows ver. 15. Hasil penelitian menunjukkan babwa $t_{\text {hitung }}=56,236$ dengan Sig $=0,000$. Karena nilai sig $<0,05$ maka dapat disimpulkan babwa terdapat pengaruh yang signifikan setelah pemberian perlakuan dalam metode bermain peran. Jadi Ho ditolak Ha diterima yang berarti terdapat pengaruh sebelum dan sesudah diberi perlakuan terhadap perkembangan sosial emosional anak. Pengaruh metode bermain peran terbadap aspek perkembangan sosial emosional anak. kelompok B di Taman Kanak-Kanak (TK) Pondok Pesantren Babussalam Pekanbaru sebesar $92,17 \%$.

Kata Kunci : Perkembangan Sosial Emosional, Metode, Bermain Peran

\section{PENDAHULUAN}

Dalam UU No. 20 Tahun 2003tentang Sistem Pendidikan Nasional, Bab 1 Pasal 1 menyebutkan bahwa Pendidikan Anak Usia Dini (PAUD) adalah suatu upaya pembinaan yang ditujukan kepada anak sejak lahir sampai dengan usia 6 tahun yang dilakukan melalui pemberian rangsangan pendidikan untuk membantu pertumbuhan dan perkembangan jasmani dan rohani agar anak memiliki kesiapan dalam memasuki pendidikan lebih lanjut.

Pada UU No. 20 Tahun 2003 dijelaskan bahwa Pendidikan Anak Usia Dini diselenggarakan sebelum jenjang Pendidikan Dasar, PAUD dapat diselenggarakan melalui jalur pendidikan formal, nonformal dan informal, PAUD jalur pendidikan formal: TK, RA atau bentuk lain yang sederajat, PAUD jalur pendidikan non formal: $\mathrm{KB}$, TPA, atau bentuk lain yang sederajat, PAUD jalur pendidikan informal: pendidikan keluarga atau pendidikan yang diselenggarakan oleh lingkungan. Dinyatakan pula bahwa yang dimaksud dengan Taman Kanak-Kanak (TK) adalah salah satu bentuk pendidikan prasekolah yang menyediakan program pendidikan dini bagi anak usia empat tahun sampai memasuki pendidikan dasar. Lebih lanjut dijelaskan bahwa satuan pendidikan prasekolah meliputi Taman Kanak-Kanak, Kelompok Bermain dan Penitipan Anak.

Pendidikan anak usia dini pada hakikatnya adalah pendidikan yang diselenggarakan dengan tujuan memfasilitasi pertumbuhan dan perkembangan anak secara menyeluruh atau menekankan pada pengembangan seluruh aspek kepribadian anak. Suyadi (2012) mengemukakan pendidikan anak usia dini diartikan sebagai salah satu bentuk penyelenggaraan pendidikan yang menitikberatkan pada peletakan dasar ke arah pertumbuhan dan perkembangan.Salah satu aspek perkembangan anak yang menjadi sangat penting dan krusial bagi anak saat mulai memasuki Lembaga Pendidikan Anak Usia Dini (PAUD) adalah perkembangan sosial dan emosionalnya yang menentukan keterampilan anak untuk berinteraksi terhadap sesama teman dan kemampuan penyesuaian diri.

Namun dalam kondisi saat ini, khususnya yang tampak pada lokasi penelitian menunjukkan bahwa masih ada beberapa anak didik yang mengalami kesulitan saat berinteraksi dan bersosialisasi dengan teman sebayanya, masih sulit untuk dimintai 
tampil oleh pendidik, dan juga ada sebagian anak yang sulit untuk berbagi peralatan mainan bersama teman disekitarnya. Novan Ardy Wiyani (2014) mengemukakan bahwa perkembangan sosial dan emosional merupakan dua aspek yang berlainan tetapi dalam kenyataannya satu sama lain saling mempengaruhi pada kesehariannya, saat berinteraksi dengan orang lain, perilaku anak selalu dilingkupi dengan perasaannya dan perasaan yang melingkupi anak juga akan berpengaruh terhadap perilaku yang dimunculkannya. Dari hasil survei terhadap orangtua dan guru diseluruh dunia,ternyata ditemukan bahwa generasi sekarang lebih banyak memiliki kesulitan emosi dan sosial dibandingkan dengan generasi sebelumnya (Ali Nugraha \& Yeni Rachmawati, 2006).

Ada beberapa metode untuk menstimulasi perkembangan sosialemosional anak yang salah satunyaadalah metode bermain peran. Mulyasa (2012) mengemukakan bahwa bermain peran adalah permainan yang dilakukan anak dengan cara memerankan tokoh-tokoh, benda-benda, binatang maupun tumbuhan yang ada disekitar anak. Melalui bermain peran, anak-anak mencoba mengeksplorasi hubungan antar manusia dengan cara memperagakannya dan mendiskusikannya sehingga secara bersama-sama dapat mengeksplorasi perasaan, sikap, nilai, dan berbagai strategi pemecahan masalah.

Untuk itu maka peneliti mencoba untuk melakukan penelitian mengenai adakah pengaruh yang muncul ketika penerapan metode bermain peran dilakukan terhadap pengembangan aspek sosial emosional anak. Tujuan penelitian ini bermaksud untuk mengetahui ada atau tidaknya pengaruh metode bermain peran terhadap perkembangan sosial emosional anak.

\section{METODE}

Jenis penelitian yang akan digunakan adalah jenis penelitian kuantitatif untuk membandingkan hasil pengukuran dua variabel yang berbeda agar dapat menentukan tingkat hubungan variabel-variabel tersebut, yang bertujuan memberikan gambaran secara sistematis tentang keadaan yang berlangsung pada objek penelitian.Penelitian ini merupakan penelitian eksperimen (experimental). Amat Jaedun (2011) mengemukakan bahwa penelitian eksperimen adalah penelitian yang digunakan untuk menentukan pengaruh variabel perlakuan (independent variable) terhadap variabel dampak (dependent variable), dilakukan terhadap variabel yang datadatanya belum ada sehingga perlu dilakukan proses manipulasi melalui pemberian treatment tertentu terhadap subjek penelitian yang kemudian diamati dan diukur. Populasi merupakan elemen penelitian yang hidup dan tinggal bersama-sama dan secara teoritis menjadi target penelitian (Johni Dimyati, 2013).

Populasi dalam penelitian ini adalah anak didik di TK Pondok Pesantren Babussalam Pekanbaru, terdiri dari enam kelas, yaitu kelas A1, A2, B1, B2, B3, dan B4 yang berjumlah keseluruhan 60 anak. Pengambilan sampel dalam penelitian ini menggunakan dua kelas, yaitu kelas B1 sebagai kelas kontrol sebanyak 10 anak dan 
B2 sebagai kelas eksperimen sebanyak 10 anak sehingga secara keseluruhan berjumlah 20 anak. Sampel merupakan bagian dari populasi atau subjek yang dipilih dan ditetapkan sebagai sumber data atau sumber informasi dari penelitian. Pengambilan sampel dilakukan dengan teknik purposive sampling, yaitu teknik penentuan sampel dengan pertimbangan tertentu (Sugiyono, 2011).

Juliansyah Noor (2012) mengemukakan bahwateknik pengumpulan data yang digunakan pada penelitian ini adalah observasi, yaitu teknik yang memerlukan dan menuntut adanya pengamatan dari peneliti baik secara langsung maupun tidak langsung terhadap objek dan subjek penelitian. Instrumen yang dapat digunakan dalam teknik observasi adalah lembar pengamatan dan panduan pengamatan. Beberapa informasi yang diperoleh dari hasil observasi antara lain terdiri dari ruang (tempat), pelaku, kegiatan, objek, perbuatan, kejadian atau peristiwa, waktu dan perasaan. Teknik pengumpulan data selanjutnya adalah dokumentasi, yaitu data yang sebagian besar berbentuk surat, catatan, laporan dan foto.Sifat utama data ini tidak terbatas pada ruang dan waktu sehingga memberi peluang kepada peneliti untuk mengetahui hal-hal yang pernah terjadi, secara detail, bahan dokumenter terbagi beberapa macam, yaitu autobiografi, surat pribadi, buku atau catatan, memorial, dokumen pemerintah atau swasta, data di server dan flashdisk, dan data tersimpan di website.

Setelah data terkumpul, selanjutkan data dianalisis menggunakan rumus statistikuji-t untuk melihat apakah ada pengaruh metode bermain peran terhadap aspek perkembangan sosial emosional anak sebelum dan sesudah diberi perlakuan.

\section{HASIL DAN PEMBAHASAN}

Pengujian hipotesis dalam penelitian ini menggunakan rumus $t$-test untuk melihat perbedaan pada kelas kontrol dan kelas eksperimen dalam melihat seberapa besar pengaruh metode bermain peran terhadap perkembangan sosial emosional anak usia dini. Data dikatakan mengalami peningkatan yang signifikan jika Sig.< 0,05. Jika Sig. $>0,05$ maka Ho diterima, Ha ditolak dan sebaliknya jika Sig. $<0,05$ maka Ho ditolak, Ha diterima. Sebelum melihat apakah ada perbedaan perkembangan sosial emosional anak didik pada kelas kontrol dan kelas eksperimen, perlu dilihat $t$-test data kelas kontrol dan kelas eksperimen.

Perbandingan dalam penelitian ini menggunakan uji statistik SPSS ver. 15 dengan paired sample t-test dimana tes ini dilakukan untuk melihat apakah terdapat perbedaan secara nyata sebelum dan sesudah menggunakan metode bermain peran terhadap perkembangan sosial emosional yang terdapat pada kelas eksperimen. Data dikatakan mengalami peningkatan yang signifikan jika Sig. $<0,05$. Jika Sig. $>0,05$ maka Ho diterima, Ha ditolak dan sebaliknya jika Sig. < 0,05 maka Ho ditolak, Ha 
diterima. Adapun hasil perbandingan pretest dan posttest pada kelas eksperimen adalah sebagai berikut:

Tabel IV. 1 Uji pretest dan posttest dalam kelas eksperimen

Paired Samples Test

\begin{tabular}{|c|c|c|c|c|c|c|c|c|c|}
\hline & \multicolumn{6}{|c|}{ Paired Differences } & \multirow{2}{*}{$\begin{array}{l}\mathrm{T} \\
-56,236\end{array}$} & \multirow{2}{*}{$\begin{array}{l}\text { Df } \\
\\
9\end{array}$} & $\begin{array}{l}\text { Sig. } \\
(2- \\
\text { tailed })\end{array}$ \\
\hline & Mean & $\begin{array}{c}\text { Std. } \\
\text { Deviatio } \\
\mathrm{n}\end{array}$ & $\begin{array}{r}\text { Std. } \\
\text { Mean }\end{array}$ & Error & $\begin{array}{l}\quad 95 \% \\
\text { Confidenc } \\
\text { Interval } \\
\text { Differenc }\end{array}$ & of the & & & ,000 \\
\hline & $\begin{array}{l}\text { Lowe } \\
\mathrm{r}\end{array}$ & Upper & Lowe & ${ }_{\mathrm{r}}$ Uppe & Lower & & & & \\
\hline $\begin{array}{l}\mathrm{P} \\
\text { air } \\
1\end{array}$ & $\begin{array}{l}\text { pre } \\
\text { test } \\
\text { post } \\
\text { test }\end{array}$ & $27,10000^{-}$ & $\begin{array}{r}1,523 \\
88\end{array}$ & $\begin{array}{r}4818 \\
9\end{array}$ & $\begin{array}{r}28,190 \\
12\end{array}$ & $\begin{array}{r}26,009 \\
88\end{array}$ & & & \\
\hline
\end{tabular}

Sumber : Uji pretest dan posttest pada kelas eksperimen

Berdasarkan tabel diatas menunjukkan nilai uji statistik t hitung sebesar 56,236 uji dua pihak berarti harga mutlak, sehingga nilai (-) tidak dipakai, sehingga $t$ hitung $=56,236$. karena nilai (Sig. 2-tailed) $=0,000<0,05$. Maka dapat peneliti simpulkan bahwa terdapat pengaruh yang signifikan setelah menggunakan metode bermain peran dalam pembelajaran.

Untuk mengetahui hipotesis diterima atau ditolak berdasarkan data spss windows for vesion 15 dapat dilihat dari perbandingan hasil t hitung dengan nilai t tabel hasil dari perhitungan uji t, terlihat bahwa hasil t hitung 56,236lebih besar dari pada ttabel $=2,262$ dengan $\mathrm{dk}$ yaitu:

$$
\begin{aligned}
& \text { Dk = n-1 } \\
& =10-1 \\
& =9
\end{aligned}
$$

Dengan $\mathrm{dk}=9$, maka dapat dilihat harga t hitung $=56,236$ lebih besar dari ttabel 2,262. Dengan demikian $\mathbf{H o}=$ ditolak dan $\mathbf{H a}=$ diterima, jadi dalam penelitian ini terdapat pengaruh metode bermain peran terhadap perkembangan sosial emosional pada anak yang berada pada kelas eksperimen.

Selanjutnya perbandingan antara pretest dan posttest kelas kontrol dalam penelitian ini menggunakan paired sample t-test dengan mengunakan program SPSS 15. Tes ini dilakukan untuk menjadikan pembanding hasil dari kelompok eksperimen. Kelas kontrol menggunakan metode pembelajaran seperti biasa. Adapun hasil perbandingan pretest dan posttest kelas kontrol : 
Tabel IV. 2 Uji pretest dan posttestdalam kelas control Paired Samples Test

\begin{tabular}{|c|c|c|c|c|c|c|c|c|}
\hline & \multicolumn{5}{|c|}{ Paired Differences } & \multirow{3}{*}{$\begin{array}{c}\mathrm{T} \\
3^{17,56}\end{array}$} & \multirow{3}{*}{$\begin{array}{l}\text { Df } \\
9\end{array}$} & \multirow{3}{*}{$\begin{array}{l}\text { Sig. } \\
(2- \\
\text { tailed) } \\
, 000\end{array}$} \\
\hline & \multirow{2}{*}{$\begin{array}{l}\text { Mean } \\
\text { Lowe } \\
\text { r }\end{array}$} & \multirow{2}{*}{$\begin{array}{l}\text { Std. } \\
\text { Deviatio } \\
\mathrm{n} \\
\text { Upper }\end{array}$} & \multirow{2}{*}{$\begin{array}{l}\text { Std. } \\
\text { Error } \\
\text { Mean } \\
\text { Lowe } \\
\mathrm{r}\end{array}$} & \multicolumn{2}{|c|}{$\begin{array}{l}95 \% \\
\text { Confidence } \\
\text { Interval of the } \\
\text { Difference }\end{array}$} & & & \\
\hline & & & & ${ }_{\mathrm{r}}^{\text {Uppe }}$ & $\mathrm{r}^{\text {Lowe }}$ & & & \\
\hline $\begin{array}{ll}\text { Pair } & \text { pr } \\
& \mathrm{e}^{-}- \\
& \text {pos } \\
& \mathrm{t}\end{array}$ & $\begin{array}{r}8,3000 \\
0\end{array}$ & $\begin{array}{r}1,4944 \\
3\end{array}$ & $\begin{array}{r}4725 \\
8\end{array}$ & $\begin{array}{r}9,3690 \\
5\end{array}$ & $\begin{array}{r}7,2309 \\
5\end{array}$ & & & \\
\hline
\end{tabular}

Sumber : Uji pretest dan posttest Kontrol (lampiran 8)

Berdasarkan tabel diatas menunjukkan nilai uji statistik t hitung sebesar 17,563 uji dua pihak berarti harga mutlak. Karena nilai (Sig. 2-tailed $)=0,000<0,05$. Maka dapat peneliti simpulkan bahwa terdapat perubahan pada kelas kontrol yang menjadi pembanding kelas eksperimen. Namun hasil yang diperoleh lebih rendah dibanding dengan kelas eksperimen.

Dapat dilihat dari perbandingan hasil t hitung dengan $t$ tabel hasil dari perhitungan uji $\mathrm{t}$, terlihat bahwa hasil $\mathrm{t}$ hitung 17,563 lebih besar dari pada $\mathrm{t}$ tabel $=$ 2,262 dengan dk yaitu:

$$
\begin{aligned}
\mathrm{Dk} & =\mathrm{n}-1 \\
& =10-1 \\
& =9
\end{aligned}
$$

Dengan $\mathrm{dk}=9$, maka dapat dilihat harga t hitung $=17,563$ lebih besar dari ttabel 2,262. Dengan demikian terdapat pengaruh dalam penggunaan metode sebelum dan sesudah terhadap perkembangan sosial emosional anak kelompok B Taman Kanak-Kanak (TK) Pondok Pesantren Babussalam Pekanbaru. Akan tetapi, nilai kelas kontrol lebih rendah dari kelas eksperimen, karena adanya perbedaan dalam penggunaan metode.

Perbandingan antara preteset kelas kontrol dan eksperimen dalam penelitian ini menggunakan uji t-test untuk melihat perbedaan pada kelas kontrol dan kelas eksperimen serta untuk melihat seberapa besar pengaruh metode bermain peran terhadap perkembangan sosial emosional anak kelompok B. Data dikatakan mengalami peningkatan yang signifikan jika Sig. $<0,05$. Jika Sig. $>0,05$ maka Ho diterima, Ha ditolak dan sebaliknya jika Sig. < 0,05 maka Ho ditolak, Ha diterima. 
Sebelum melihat apakah ada perbedaan perkembangan sosial emosional anak pada kelas kontrol dan kelas eksperimen, perlu dilihat koefisien data kelas kontrol dan kelas eksperimen seperti di bawah ini:

Tabel IV. 3 Pretest kelas eksperimen dan kelas control One-Sample Test

\begin{tabular}{|c|c|c|c|c|c|c|c|}
\hline & \multicolumn{7}{|c|}{ Test Value $=90$} \\
\hline & \multirow{2}{*}{$\begin{array}{l}\mathrm{T} \\
\text { Lower }\end{array}$} & \multirow{2}{*}{$\begin{array}{l}\text { Df } \\
\text { Upper }\end{array}$} & \multirow{2}{*}{\multicolumn{2}{|c|}{\begin{tabular}{|c|}
$\begin{array}{c}\text { Sig. } \\
\text { tailed) }\end{array}$ \\
Lower
\end{tabular}}} & \multirow{2}{*}{$\begin{array}{c}\text { Mean } \\
\text { Difference }\end{array}$} & \multicolumn{2}{|c|}{$\begin{array}{l}95 \% \text { Confidence Interval } \\
\text { of the Difference }\end{array}$} \\
\hline & & & & & & Lower & Upper \\
\hline Pre & 64,911 & 9 & & 000 & 10,60000 & 10,2306 & 10,9694 \\
\hline Test & 39,000 & 9 & & 000 & 11,70000 & 11,0214 & 12,3786 \\
\hline
\end{tabular}

Sumber : Uji pretest kelas eksperimen dan kontrol (Lampiran 8)

Berdasarkan tabel diatas menunjukkan nilai uji statistik t hitung sebesar 64,911 uji dua pihak berarti harga mutlak. Karena nilai (Sig. 2-tailed) $=0,000<0,05$. Maka peneliti menyimpulkan bahwa terdapat perbedaan perkembangan sosial emosional anak sebelum pemberian treatment menggunakan metode bermain peran.

Untuk mengetahui hipotesis diterima atau ditolak berdasarkan data SPPS windows for vesion15 dapat dilihat dari perbandingan hasil t hitung dengan nilai ttabel dari perhitungan uji t, terlihat bahwa hasil t hitung 64,911lebih besar dari pada $\mathrm{t}$ tabel $=2,101$ dengan dk yaitu:

$$
\begin{aligned}
\text { Dk } & =\mathrm{n} 1+\mathrm{n} 2-2 \\
& =10+10-2 \\
& =18
\end{aligned}
$$

Dengan $\mathrm{dk}=18$, maka dapat dilihat harga $\mathrm{t}$ hitung $=64,911$ lebih besar dari ttabel $=2,101$. Dengan demikian $\mathbf{H a}=$ diterima dan $\mathbf{H o}=$ ditolak. Jadi, artinya ada perbedaan nilai rata-rata antara kelas eksperimen dan kelas kontrol sebelum diberi perlakuan (pretest).

Selanjutnya perbandingan posttest antara kelas kontrol dan eksperimendalam penelitian ini menggunakan rumus t-testuntuk melihat perbedaan pada kelas eksperimen dan kelas kontrol untuk melihat seberapa besar pengaruh metode bermain peran terhadap perkembangan sosial emosional anak usia dini. Data dikatakan mengalami peningkatan yang signifikan jika Sig. $<0,05$. Jika Sig. $>0,05$ maka Ho diterima, Ha ditolak sebaliknya jika Sig. $<0,05$ maka Ho ditolak, Ha diterima. Sebelum melihat apaka ada perbedaan perkembangan sosial emosional anak didik pada kelas eksperimen dan kelas kontrol, perlu dilihat koefisien korelasi data kelas eksperimen dan kelas kontrol seperti tabel berikut: 
Tabel IV. 4 Uji posttest kelas eksperimen dan kelas control One-Sample Test

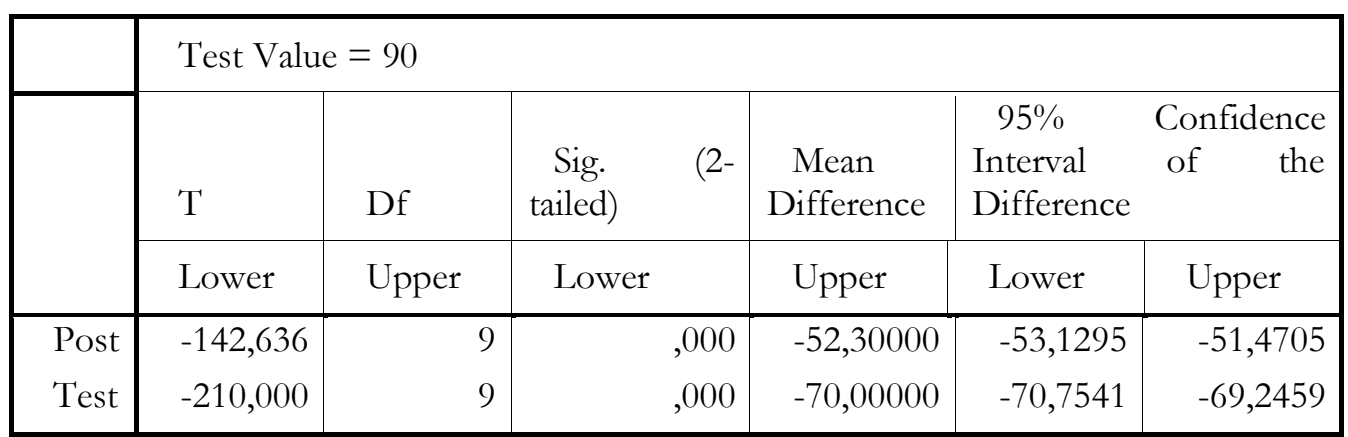

Sumber : Posttest Kelas Eksperimen Dan Kelas Kontrol (Lampiran 8)

Berdasarkan tabel di atas menunjukan nilai uji statistik t hitung sebesar 142,636uji dua pihak berarti harga mutlak, sehingga nilai (-) tidak dipakai. Sehingga t hitung 142,636, karena nilai (Sig. 2-tailed) $=0.000<0.05$. Maka dapat di tarik kesimpulan bahwa $\mathbf{H o}=$ ditolak dan $\mathbf{H a}=$ diterima itu artinya ada perbedaan nilai rata-rata antara kelas eksperimen dan kelas kontrol sesudah diberi perlakuan (posttest).

Dapat dilihat dari perbandingan hasil t hitung dengan nilaittabel hasil dari perhitungan uji t, terlihat bahwa $\mathrm{t}$ hitung 142,636 lebih besar dari ttabel= 2,101dengan dk yaitu:

$$
\begin{aligned}
\text { Dk } & =\mathrm{n} 1+\mathrm{n} 2-2 \\
& =10+10-2 \\
& =18
\end{aligned}
$$

Dengan $\mathrm{dk}=28$, maka dapat dilihat harga $\mathrm{t}$ hitung $=142,636$ lebih besar dari $\mathrm{t}$ tabel $=2,101$. Dengan demikian $\mathbf{H o}=$ ditolak dan $\mathbf{H a}=$ diterima. Artinya ada pengaruh signifikan antara kelas eksperimen yang diberi perlakuan menggunakan metode bermain peran dengan kelas kontrol yang tidak diberi perlakuan dan tanpa menggunakan metode bermain peran. Jadi dalam penelitian ini ada pengaruh metode bermain peran terhadap perkembangan sosial emosional anak.

Untuk mengetahui seberapa besar pengaruh metode bermain peran terhadap perkembangan sosial emosional anak, maka digunakanlah rumus Gain ternormalisasi.

Berdasarkan hasil dapat diketahui bahwa pengaruh yang diberikan dalam penggunaan metode bermain peranterhadap perkembangan sosial emosional anak adalah sebesar 92,17\%. Terdapat 3 kategori perolehan skor gain ternormalisasi yaitu: 
Tabel IV. 5 Kategori gain ternormalisasi

\begin{tabular}{cc}
\hline \multicolumn{2}{c}{ Gain Ternormalisasi } \\
\hline Gain Ternormalisasi & Kriteria Penilaian \\
$\mathrm{G}<30$ & Rendah \\
$30 \%<\mathrm{G}<70 \%$ & Sedang \\
$\mathrm{G}>70 \%$ & Tinggi \\
\hline
\end{tabular}

Merujuk pada hasil penggunaan rumus gain ternormalisasi di atas, maka dapat dilihat kategori peningkatan sebesar $92,17 \%$ yaitu berada pada kategori tinggi $92,17 \%>70 \%$.

Berdasarkan analisis pengelolaan data dan hasil presentasi di atas dapat dilihat hasil pretest perkembangan sosial emosional anak kelompok B di Taman KanakKanak (TK) Pondok Pesantren Babussalam Pekanbaru diperoleh jumlah nilai 117 dengan rata-rata 11,7 pada kelas kontrol dan 106 dengan rata-rata 10,6 pada kelas eksperimen. Jika dilihat dari kriteria perorangan, tidak ada anak yang berada pada kriteria BSB, BSH, MB atau 0\% pada kedua kelas baik kelas eksperimen dan kelas kontrol, yang berada pada BB sebanyak 10 orang atau 100\% pada kelas kontrol dan pada kelas eksperimen.

Berdasarkan data di atas artinya perkembangan sosial emosional pada anak saat pretest masih rendah. Terbukti saat proses pembelajaran, peneliti melakukan pengamatan kepada anak secara langsung dan dapat dilihat perkembangan sosial emosional anak kelompok B di Taman Kanak-Kanak (TK) Pondok Pesantren Babussalam masih rendah, dimana anak masih belum mampu mengekspresikan perasaannya, belum mampu bersikap kooperatif dan aktif, belum mampu bersosialisasi dan berinteraksi dengan teman sebaya secara baik. Ini menandakan bahwa metode yang sering digunakan guru untuk mengembangkan perkembangan sosial emosional anak di Taman Kanak-Kanak (TK) Pondok Pesantren Babussalam Pekanbaru ternyata belum sepenuhnya dapat mengembangkan aspek perkembangan sosial emosional anak secara sempurna. Rendahnya perkembangan sosial emosional pada anak disebabkan oleh metode atau permainan yang kurang menarik saat pembelajaran sehingga membuat anak kurang bersemangat mengikuti pembelajaran dan anak tidak dapat mengikuti pembelajaran dengan serius.

Berdasarkan hasil yang telah dicapai pada pretest maka perlu dilakukan peningkatan perkembangan sosial emosional pada anak melalui treatment dengan mengunakan metode bermain peran. Melalui metode ini diharapkan anak dapat termotivasi untuk berinteraksi aktif dengan teman sebayanya, melatih keberaniannya untuk tampil ke depan, dan menstimulasi untuk anak mampu mengekspresikan perasaannya. Metode bermain peran ini dijadikan stimulus dalam pembelajaran agar kemampuan sosial emosional anak dapat meningkat. Metode bermain peran digunakan karena diperkirakan dapat memberi suasana yang berbeda terhadap 
pembelajaran pengembangan kemampuan sosial emosional anak di Taman KanakKanak (TK) Pondok Pesantren Babussalam Pekanbaru.

Setelah pemberian treatment dengan menerapkan metode bermain peran di Taman Kanak-Kanak (TK) Pondok Pesantren Babussalam Pekanbaru, anak memperlihatkan antusiasme ketika melakukan kegiatan berpura-pura beradegan satu persatu di depan kelas. Anak dengan senang mempraktekkan dan menirukan suatu tokoh yang diajarkan oleh gurunya dan mulai berani menampilkan diri dihadapan teman-teman yang lain. Bahkan ada anak yang sudah aktif dan mendalami karakter tokoh tanpa bantuan guru lagi. Guru hanya mengarahkan anak diawal presentasi saja. Setelah anak menggunakan metode bermain peran dilakukan evaluasi terhadap perkembangan sosial emosional anak. Berikut paparan datanya setelah dilakukan posttest diperolehjumlah nilai 200 dengan nilai rata-rata 20 pada kelas kontrol dan kelas eksperimen 377 dengan rata-rata 37,7. Peningkatan nilai rata-rata pada kelas eksperimen sangat terlihat pada saat pretest, rata-ratanya adalah 10,6 dan meningkat pada saat posttest menjadi 37,7 setelah menggunakan metode bermain peran. Ini terlihat bahwa pada kelas kontrol peningkatan tidak terlalu tinggi sedangkan pada kelas eksperimen terjadi peningkatan yang cukup tinggi. Pada kelas kontrol tidak terlalu tinggi karena hanya melakukan kegiatan seperti biasa tanpa memberikan perlakuan. Jika dilihat secara perorangan sesudah diberi treatment pada kelas eksperimen maka berada pada kriteria BSB sebanyak populasi yang diambil dengan presantase 100\%, dan tidak ada anak yang berada pada kriteria BSH, MB dan BB.

Perkembangan sosial emosional secara efektif merupakan suatu unsur penting dalam keberhasilan dalam suatu bidang kehidupan. Hal ini dapat dilihat dari meningkatnya nilai aspek perkembangan yang dicapai oleh anak, yang mana terlihat pada pretest kelas eksperimen yang telah diberi treatment anak memperoleh rata-rata nilai 10,6 dan meningkat pada posttest menjadi 37,7.

Hal ini membuktikan bahwa penggunaan metode bermain peran terbukti dapat meningkatkan perkembangan sosial emosional anak didik di Taman Kanak-Kanak (TK) Pondok Pesantren Babussalam Pekanbaru. Berdasarkan posttest yang dilakukan peneliti dapat dilihat pada proses pembelajaran bahwa anak sudah mampu berinteraksi aktif dengan teman sebayanya, melatih keberaniannya untuk tampil ke depan, dan menstimulasi untuk anak mampu mengekspresikan perasaannya.

Hal ini berarti bahwa salah satu cara untuk meningkatkan perkembangan sosial emosional anak dengan menggunakan metode bermain peran yang pada akhirnya akan meningkatkan kemampuan sosial emosional anak didik, hasil penelitian ini menunjukkan bahwa sumbangan efektif penggunaan metode bermain peran terhadap perkembangan sosial emosional anak didik sebesar 92,17\% dan 7,83\% karena faktor lain. 


\section{KESIMPULAN}

Berdasarkan hasil penelitian yang telah dilaksanakan, maka dapat disimpulkan bahwa pengaruh metode bermain peran terhadap aspek perkembangan sosial emosional anak adalah Signifikan. Hasil pengujian menunjukkan bahwa hipotesis penelitian yang diajukan dalam penelitian ini diterima, dengan thitung $=56,236 \mathrm{dan}$ Sig $=(0,000<0,05)$, yang artinya adalah Ho ditolak dan $\mathrm{Ha}$ diterima. Maka terdapat pengaruh metode bermain peran terhadap aspek perkembangan sosial emosional anak sebesar 92,17\%.

\section{DAFTAR PUSTAKA}

Al-Qur'an dan Terjemah. Syaamil Qur'an. Bandung: Departemen Agama RI

Coughlin,Pamela.A.(2000).Menciptakan Kelas Yang Berpusat Pada Anak.Children's Resources International: INC

Dimyati, Johni. (2013). Metodologi Penelitian Pendidikan \& Aplikasinya pada Pendidikan Anak Usia Dini. Jakarta: Kencana Prenada Media Group

Fitri, Ahyani Radhiani,dkk.(2013).Emosi Aplikasi Psikologi Dalam Kebidupan Pribadi Muslim. Pekanbaru:Suska Press

Jaedun, Amat. (2011). Metodologi Penelitian Eksperimen. Jogjakarta: Puslit Dikdasmen. Lemlit UNY

Latan, Hengky. (2014). Aplikasi Analisis Data Statistik Untuk Ilmu Sosial Sains dengan IBM SPPS. Bandung: Alfabet

Latif, Mukhtar,dkk.(2013).Pendidikan Anak Usia Dini Teori dan Implikasi. Jakarta: Kencana Prenada Media Group

Martani, Wisjnu.(2012). Metode Stimulasi dan Perkembangan Emosi Anak Usia Dini. Jogjakarta: Universitas Gadjah Mada. Jurnal

Mayar,Farida.(2013).Perkembangan Sosial Anak Usia Dini Sebagai Bibit Untuk Masa Depan Bangsa.Padang:UNP

Moeslichatoen R.(2004).Metode Bermain Anak TK.Jakarta: PT Rineka Cipta

Muliawan,Jasa Ungguh.(2009).Tips jitu Memilih Mainan positif \& Kreatif Untuk Anak Anda.Jogjakarta: Diva Press

Mulyasa.(2012).Manajemen PAUD.Bandung:Remaja Rosdakarya

Mutiah,Diana.(2010).Psikologi Bermain Anak Usia Dini.Jakarta:Kencana Prenada Media Group

Noor, Juliansyah. (2012). Metodologi Penelitian. Jakarta: Kencana Prenada Media Group

Nugraha,Ali.Yeni Rachmawati.(2006). Metode Pengembangan Sosial Emosional. Jakarta: Universitas Terbuka 
Nurmalitasari, Femmi. (2015). Perkembangan Sosial Emosional pada Anak Usia Prasekolah. Jurnal

Nursyahidah,Farida.Penelitian Eksperimen, dalam Jurnal

Santrock,John W.(2007).Perkembangan Anak.Erlangga

Soetjiningsih,Christiana Hari.(2012).Perkembangan Anak.Jakarta: Kencana Prenada Media Group

Sugiyono. (2011). Metode Penelitian Kuantitatif Kualitatif dan R\&D. Bandung: Alfabet

Suharto. (2013). Pendekatan dan Teknik Belajar dalam Proses Belajar Mengajar. Bandung: Tarsito

Suyadi \& Ulfah,Maulidya.(2013).Konsep Dasar PAUD.Bandung:PT Remaja Rosdakarya

Tirtayani,Luh Ayu,dkk.(2014).Perkembangan Sosial Emosional Pada Anak Usia Dini.Jogjakarta:Graha Ilmu

Umama. (2007). Checklist Indikator Anak 0-6 Tabun: Pusat Kurikulum Diknas

Widiatmoko,Hani.(2014).Ketika Anakku Siap Menikah. Jakarta:PT Elex Media Komputindo

Wiyani, Novan Ardy.(2014).Psikologi Perkembangan Anak Usia Dini. Jogjakarta: Gava Media 